blood urea rose to $61 \mathrm{mg} . / 100 \mathrm{ml}$., but subsequently fell to well within normal limits.

If this patient had given a kidney to her twin sister there is every likelihood that it would have been the left one which would have been used. It could therefore be argued that if she had been used as a donor she would have been spared the lengthy illness described above, as there would have been no left kidney to form a fistula into the cervix. However, what if the ureter to be damaged by the caesarean section had been a right and only ureter because the left one had previously been removed? There is also the fact that this patient had a urinary infection with hospital type of coliform organisms resistant to several antibiotics commonly used in the treatment of urinary infections, and this may recrudesce to give further trouble. Late stenotic complications following ureteric anastomosis are not unknown. We feel thankful that this patient had not been used as a kidney donor, although at the time that this was considered we did not think that there was any ethical objection to the use of an identical twin as a kidney donor.

In view of this experience and the fact that it has been reported many times that glomerulonephritis can recur in a transplanted kidney we would now have reservations to the use of any young person, even if an identical twin, as a donor.-We are, etc.,

\section{Department of Nephrology.}

Mary G. McGeown.

Belfast City Hospital,
Belfast.

\section{Department of Urology,}

JOSEPH A. KENNEDY.

Belfast.

REFBRENCES

1 Murray, J. B., and Lynch, J. J., J. Amer. med. $=$ Brit. med. F., 1962, 2, 532.

\section{Radioactive Corpses}

SIR,-With reference to your leading article on Radioactive Corpses (6 May, p. 331) the method in use at this institute for warning the mortuary attendant that a body is radioactive is as follows.

For all large radioisotope therapy doses the patient is admitted for an appropriate time dependent on the nature of the isotope, and its biological half-life, and a note is sent to the pathologist to the effect that "If patient X presents for necropsy before a certain date he is to be regarded as a radioactive hazard and the physicist called." This note is pinned behind the mortuary door and discarded after the given date. The responsibility for the issue of this note lies with the senior staff of the radioisotope unit.- I am, etc.,

\section{Cancer Institute,
Melbourne, Australia.}

\section{Health of Students and Soldiers}

SIR,-I read your leading article "Health of University Students" (20 May, p. 457) with considerable interest, and would heartily endorse the policy adrocated regarding the state of rapprochement required in the staff/ student complex.

I must, however, take issue-if I have interpreted the wording aright-with the suggestion that the control of health in the armed Forces carries a lesser personal touch than that in universities. Certainly, so far as the Army is concerned, and I believe that similar principles apply in the other Services, great emphasis is laid on this very aspect of man-management. If control is to be exercised in any context, then responsibility must be defined. In the Army, responsibility for health devolves on its commanders (in the broadest sense), advised or assisted by the medical services.

While it would obviously be unrealistic to expect a divisional commander and his assistant director of medical services to be au fait with the health problems of every man in the division, it is a very different story when one comes down to regimental or battalion level. By tradition, and in practice, this is a close-knit, almost a family community. It would be absolutely wrong to judge that the "usual channels," as might be implied by the less well-informed reader of your leading article, inevitably lead to an impersonal approach to matters of health.

The regimental officer is fitted by training

\section{Smoking and Atherosclerosis}

SIR,-In a previous letter on this subject (16 April 1966, p. 984) I suggested that smoking and dietary sugar affect the arteries in a similar way. Further work with the help of heavy-smoker volunteers indicates that the atherogenic effect of smoking might lie in its ability to induce hyperinsulinism. This conclusion is based on the following experiment.

Twelve male and seven female volunteers were chosen with the only criterion in their selection that they habitually smoked 20 cigarettes, or more, per day. Their ages ranged and by situation to be qualified, perhaps uniquely so, to observe, to advise, and generally to care for the men under his command. And associated with the regimental officer in the field of health, and in their common goal of conservation of highly and expensively trained military manpower, is the regimental medical officer. $\mathrm{He}$ is the man who must fulfil many roles, both advisory and executive. He does not necessarily wait to be asked for advice, although he must be freely available for consultation. It is his duty to identify himself with his unit, to know its role, to acquire a knowledge of the tasks undertaken by its members, and to help seek out weak or potentially weak links in the health chain, whether these are personal or environmental.

It might indeed be postulated that any university planning a health service could do very much worse than to base this on the practice of the nearest regular battalion of one of our county regiments.-I am, etc.,

Royal Army Medical College, H. G. SRINNER.
London S.W.1.

fasting cigarettes, and during the glucose tolerance test. The values found during the period of heavy smoking and after the cessation of smoking for 14 days may also be compared.

If excessive insulin response can be defined as insulin levels rising above 100 microunits per ml. serum during an oral glucose tolerance test ${ }^{2}$ then subject No. 4 may not be considered to have hyperinsulinaemia. However, the marked drop in insulin response after she stopped smoking for 14 days indicates a relative hyperinsulinism during the

Comparison of Blood Glucose and Serum Insulin Levels

\begin{tabular}{|c|c|c|c|c|c|c|c|c|c|c|c|}
\hline \multirow{3}{*}{$\begin{array}{l}\text { Sub- } \\
\text { ject } \\
\text { and } \\
\text { Sex }\end{array}$} & \multirow{3}{*}{ Stage of Trial } & \multicolumn{5}{|c|}{ Glucose (mg./100 ml. Blood) } & \multicolumn{5}{|c|}{ Insulin ( $\mu \mathrm{u} . / \mathrm{ml}$. Serum) } \\
\hline & & \multicolumn{2}{|c|}{ Fasting } & \multirow[b]{2}{*}{$\begin{array}{l}30 \\
\text { min. }\end{array}$} & \multirow[b]{2}{*}{$\begin{array}{l}60 \\
\min .\end{array}$} & \multirow[b]{2}{*}{$\begin{array}{l}120 \\
\text { min. }\end{array}$} & \multicolumn{2}{|c|}{ Fasting } & \multirow[b]{2}{*}{$\begin{array}{l}30 \\
\text { min. }\end{array}$} & \multirow[b]{2}{*}{$\begin{array}{l}60 \\
\text { min. }\end{array}$} & \multirow[b]{2}{*}{$\begin{array}{l}120 \\
\min .\end{array}$} \\
\hline & & $\begin{array}{c}\text { Before } \\
\text { Smok- } \\
\text { ing }\end{array}$ & $\begin{array}{l}\text { After 2 } \\
\text { Cigar } \\
\text { ettes }\end{array}$ & & & & $\begin{array}{c}\text { Before } \\
\text { Smok- } \\
\text { ing }\end{array}$ & $\begin{array}{l}\text { After 2 } \\
\text { Cigar- } \\
\text { ettes }\end{array}$ & & & \\
\hline $1 \mathrm{M}$ & $\begin{array}{l}30 \text { cigarettes/day } . . \\
\text { Stopped } 14 \text { days }\end{array}$ & $\begin{array}{l}92 \\
73\end{array}$ & $\begin{array}{r}100 \\
78\end{array}$ & $\begin{array}{l}151 \\
136\end{array}$ & $\begin{array}{l}112 \\
105\end{array}$ & $\begin{array}{l}90 \\
70\end{array}$ & $\begin{array}{l}87 \\
29\end{array}$ & $\begin{array}{l}96 \\
32\end{array}$ & $\begin{array}{r}150 \\
54\end{array}$ & $\begin{array}{r}156 \\
67\end{array}$ & $\begin{array}{r}102 \\
47\end{array}$ \\
\hline $2 M$ & $\begin{array}{l}\text { 30-40 cigarettes/day } \\
\text { Stopped } 14 \text { days } \ldots\end{array}$ & $\begin{array}{l}85 \\
66\end{array}$ & $\begin{array}{l}90 \\
83\end{array}$ & $\begin{array}{l}127 \\
112\end{array}$ & $\begin{array}{l}103 \\
100\end{array}$ & $\begin{array}{l}84 \\
80\end{array}$ & $\begin{array}{l}52 \\
35\end{array}$ & $\begin{array}{l}58 \\
40\end{array}$ & $\begin{array}{r}112 \\
63\end{array}$ & $\begin{array}{l}100 \\
57\end{array}$ & $\begin{array}{l}61 \\
38\end{array}$ \\
\hline $3 \mathbf{F}$ & $\begin{array}{l}25-30 \text { cigarettes/day } \\
\text { Stopped } 14 \text { days } . .\end{array}$ & $\begin{array}{l}98 \\
54 \\
\end{array}$ & $\begin{array}{r}95 \\
81 \\
\end{array}$ & $\begin{array}{l}134 \\
126 \\
\end{array}$ & $\begin{array}{l}119 \\
102 \\
\end{array}$ & $\begin{array}{l}88 \\
80 \\
\end{array}$ & $\begin{array}{l}99 \\
86\end{array}$ & $\begin{array}{l}96 \\
88 \\
\end{array}$ & $\begin{array}{l}145 \\
112 \\
\end{array}$ & $\begin{array}{l}158 \\
110 \\
\end{array}$ & $\begin{array}{l}98 \\
91 \\
\end{array}$ \\
\hline $4 \mathrm{~F}$ & $\begin{array}{l}20-30 \text { cigarettes/day } \\
\text { Stopped } 14 \text { days } . .\end{array}$ & $\begin{array}{l}90 \\
73\end{array}$ & $\begin{array}{r}98 \\
108\end{array}$ & $\begin{array}{l}145 \\
141\end{array}$ & $\begin{array}{l}120 \\
118\end{array}$ & $\begin{array}{l}87 \\
80\end{array}$ & $\begin{array}{r}33 \\
8\end{array}$ & $\begin{array}{l}30 \\
11\end{array}$ & $\begin{array}{l}95 \\
26\end{array}$ & $\begin{array}{l}84 \\
22\end{array}$ & $\begin{array}{l}40 \\
13\end{array}$ \\
\hline $5 \mathrm{M}$ & $\begin{array}{l}50 \text { cigarettes/day } . . \\
\text { Stopped } 14 \text { days } . .\end{array}$ & $\begin{array}{l}78 \\
69\end{array}$ & 84 & $\begin{array}{l}135 \\
137\end{array}$ & $\begin{array}{r}100 \\
99\end{array}$ & $\begin{array}{l}89 \\
90\end{array}$ & $\begin{array}{l}53 \\
30\end{array}$ & $\begin{array}{l}50 \\
34\end{array}$ & $\begin{array}{r}149 \\
86\end{array}$ & $\begin{array}{r}124 \\
72\end{array}$ & $\begin{array}{l}80 \\
66\end{array}$ \\
\hline
\end{tabular}

from 25 to 57 years. After explaining the purpose of the trial, the subjects were asked to fast overnight and abstain from smoking until a fasting blood sample was taken. Each subject then smoked two cigarettes in succession while talking to each other or reading magazines. A second specimen of blood was then withdrawn. After this, each subject was given 100 glucose in water, and further specimens of blood were collected at set intervals for blood glucose and serum insulin estimations. According to the original plan, subjects volunteered to abstain from smoking for 14 days after the first part of the experiment, but only three males and two females were able to do so. The above test was then repeated on these subjects. Glucose levels were estimated by the method of Folin and $W u$, and serum insulin by immunoassay.

In the accompanying Table are shown the period of heavy smoking. The view that hyperinsulinaemia is atherogenic is well documented. ${ }^{2-5}$ The suggestion that it is the factor responsible for the liability of heavy smokers to develop atherosclerosis is an expansion of this theory.-I am, etc.,

Department of Nutrition,

Stephen Szanto.

Queen Blizabeth College.

REPBRENCES

I Grodsky, G. M., Karam, J. H., Pavlatos, F. C., and Forsham, P. H., Lancet $1965,1,290$. and Pelkonen, R., ibid. i965, 2, 508.

Peters, N., and Hales, C. N.. ibid., 1965, 1,1144 Vallance-Owen, J., Quart. J. Med. 1965, 34, 485. A. H., Dollery, C. T., and Fraser, T. R. 